\title{
Ranchland Ownership Change in the Greater Yellowstone Ecosystem, 1990-2001: Implications for Conservation
}

\author{
HANNAH GOSNELL \\ Center of the American West, University of Colorado, Boulder, \\ Colorado, USA
}

\section{JULIA H. HAGGERTY}

Centre for the Study of Agriculture, Food, and the Environment, University of Otago, Dunedin, New Zealand

\section{WILLIAM R. TRAVIS}

Department of Geography, University of Colorado, Boulder, Colorado, USA

\begin{abstract}
Most of the public lands protected for conservation in the western United States are surrounded by working landscapes of various types, typically in agro-pastoral ownership and use. How these working landscapes evolve over time and how their inhabitants respond to various conservation goals will in large measure determine the success or failure of efforts to maintain regional biodiversity. This article contributes to a better understanding of ecological threat on the important private lands of the Greater Yellowstone Ecosystem by suggesting the ways in which changes in ranch ownership become conservation opportunities or challenges. Relying on a combination of real estate sales data, land ownership data, and interviews with key informants, we assess trends and patterns of ownership change around Yellowstone National Park. The main ranchland dynamic in this region involves the transition from traditional ranchers, typically full-time livestock producers, to a more diverse cohort of landowners, including absentee owners focused on amenity or conservation values in addition to, or instead of, livestock production. We present a conceptual model for distinguishing between different ranch landscapes and discuss some of the conservation implications of these geographical patterns.
\end{abstract}

Received 31 May 2005; accepted 12 October 2005.

This research was funded by the William and Flora Hewlett Foundation and Yellowstone Heritage. The authors acknowledge with gratitude the mapmaking and technical skills of Thomas W. Dickinson and Geneva Mixon, and the thoughtful advice of Mike Clark, Patrick Hurley, and several anonymous reviewers. We are also indebted to the many people in the Wyoming and Montana communities we studied who gave us their time and shared their data and insights.

Address correspondence to Hannah Gosnell, Department of Geosciences, 104 Wilkinson Hall, Oregon State University, Corvallis, OR 97331-5506, USA. E-mail: gosnellh@geo. oregonstate.edu 
Keywords amenity owners, Greater Yellowstone Ecosystem, land tenure, ownership fragmentation, ranch conservation, rural land use, transboundary conservation

The key land use tool for preserving global biodiversity is the nature preserve or protected area, which takes various forms around the world (Lucas 1992). In the United States, the largest protected areas are federal preserves (national parks and wilderness areas), surrounded by a mix of other public lands with varying intensities of human use, as well as private lands with various levels of development. By dint of history and geography, most preserves in the United States are surrounded by working landscapes of various types, typically in agro-pastoral ownership and use, along with small settlements and tourist facilities. These adjacent lands often provide a critical, though transformed, part of the ecosystem formally preserved inside the core protected area, ideally acting as "buffer zones" between the preserve and more developed lands (Groom et al. 1999). How these working landscapes evolve over time and how their inhabitants respond to the conservation goals of the protected area will in large measure determine resource managers' ability to sustain global biodiversity via the preserve system. This article contributes to a better understanding of ecological threat on the important private lands of the Greater Yellowstone Ecosystem by suggesting the ways in which changes in ranch ownership become conservation opportunities or challenges.

Preserve managers increasingly recognize the need to manage biodiversity across administrative boundaries, and scholars have begun to address the relevant issues and challenges that come up in such endeavors (Franklin 1993; Knight and Landres 1998; Brunson 1998; Bergmann and Bliss 2004). One challenge has to do with change in ownership and use of private lands adjacent to protected areas. Physical fragmentation related to subdivision for housing is an obvious threat (Knight et al. 1995; Riebsame et al. 1996; Theobald et al. 1996), but even in landscapes that look intact, underlying parcelization patterns reveal varying levels of ownership fragmentation (Walker et al. 2003). Landscapes that are legally (if not physically) fragmented into multiple individual private parcels present challenges to resource managers due to the increasingly wide-ranging sets of values, beliefs, motivations, and economic circumstances of owners associated with amenity migration, as well as great uncertainty about land use and future land fragmentation (Walker and Fortmann 2003; Jones et al. 2003; Smith and Krannich 2000; Rudzitis 1996; 1999; Fortmann and Kusel 1990; Lowe and Pinhey 1982; Graber 1974).

Ownership change, even without fragmentation, can affect conservation potential. Rural landscapes adjacent to high-amenity protected areas in the western United States are dominated by pastoral operations, or ranches, that have become attractive to nonagricultural owners (Walker et al. 2003). Ranch ownership is changing rapidly and is shifting to a cohort that is less dependent on livestock for income and more interested in maintaining and enhancing environmental amenities (Gosnell and Travis 2005). New tenure patterns appear to be introducing new land use values to many of the West's working landscapes (Haggerty and Travis, in press; Tanaka et al. 2004; Walker et al. 2003). These developments suggest the need to assess land ownership and land use trends on working lands adjacent to protected areas for their potential "compatible use" (Zimmerer and Young 1998; Soule and Terborgh 1999; Zimmerer 2000).

In this project we assessed current levels of ownership fragmentation and recent trends in ownership change around Yellowstone National Park, a major nature 
preserve. After presenting our findings, we consider how conservation opportunities and challenges vary in different types of ranch landscapes, and offer a conceptual model that can help ecosystem managers implement strategies reflecting different social landscapes.

\section{Ranchlands in the Greater Yellowstone Ecosystem}

The Greater Yellowstone Ecosystem (GYE), roughly 18 million acres in three states (WY, MT, ID), is a temperate montane ecosystem in the U.S. Rocky Mountain physiographic province with Yellowstone and Grand Teton National Parks at its core. The region is often described as the largest intact ecosystem in the lower 48 states. Some $75 \%$ of this land area is in public ownership, including national parks, national forests, national wildlife refuges, and Bureau of Land Management lands. Private lands, though they comprise only $25 \%$ of the total area, lie along lowelevation riparian corridors and have been shown to play a critical role in an ecosystem in which biodiversity declines as elevation increases (Hansen and Rotella 2002). Glick et al. (1991) estimated that private land subject to ownership change amounts to $19 \%$ of the GYE. Nearly all of this land is in agricultural ownership, with only a small percentage urbanized.

Ranches comprise the largest blocks of private land in the GYE, and, as such, provide critical wildlife habitat and open spaces (Hansen and Rotella 2002). While comprehensive data on formal protection of private land are unavailable, expert opinion and a data set on conservation easements in Montana suggest that less than 5\% of the ecosystem's private lands are formally protected (MNHP 2003). This figure underscores the importance of the land use practices of ranch owners in the GYE to biodiversity conservation.

Historically, ranch landscapes bordering Yellowstone have presented challenges to biodiversity conservation because of sometimes incompatible land use practices like monocrop agriculture, predator control, and forage competition with native ungulates (Groom et al. 1999; Glick and Clark 1998). Macroscale, regional economic and social trends in the GYE, however, have resulted in a new ownership regime and are creating new land conservation opportunities and constraints, changing the role of ranchlands in the ecosystem (Hansen et al. 2002; Frentz et al. 2004).

In a recent multicriteria conservation assessment of the GYE, Noss et al. (2002) used measures of vulnerability and "irreplaceability" to distinguish between different landscapes and aid conservationists in prioritizing and planning. Their assessment of irreplaceability drew heavily on biological data, but their analysis of vulnerability was largely based on generic categories of formal protection and expert opinion. Our work contributes to a more refined understanding of ecological threat on the important private lands of the GYE by suggesting the ways in which changes in ranch ownership become conservation opportunities or challenges.

\section{Research Methods}

We examined ranchland ownership dynamics between 1990 and 2001 in 10 GYE counties in Montana and Wyoming (Figure 1). Because we relied on county data and GYE boundaries do not coincide with county boundaries, our analysis includes some private lands that fall outside of the conventional ecological boundaries of the GYE (Greater Yellowstone Coalition 1994). Given our focus on the changing potential for land conservation, we examined ownership change only on larger ranch 


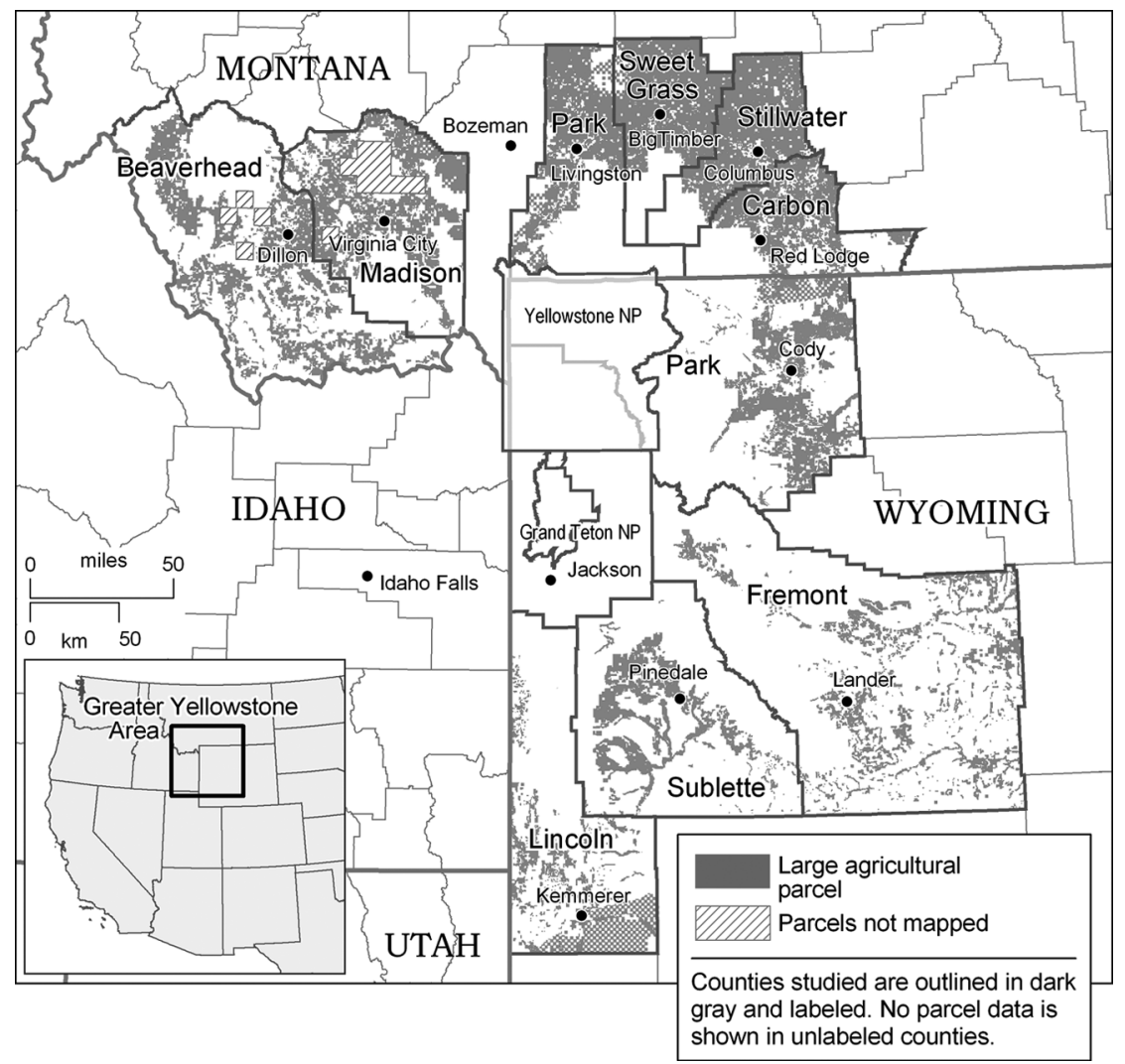

Figure 1. The 10-county study area in the Greater Yellowstone Ecosystem. Large agricultural land ownership (owners' total holdings $\geq 400$ acres) is indicated in dark gray. White areas in studied counties are predominantly public lands.

properties (400 deeded acres or more) in GYE counties with significant remaining intact ranchland because they offer greater conservation potential; we omitted counties that feature extensive resort or urban development (e.g., Teton County, WY, which includes Jackson Hole, the region's largest resort; and Gallatin County, MT, which includes the Big Sky resort and Bozeman, the region's largest city). Our results must be considered in light of the absence of these two counties, because they do not capture areas where developers play a driving role in land sales. We did not study Idaho because of the difficulty of developing a suitable methodology that could account for the prevalence of crop agriculture there.

We gathered sales data from public and private appraisers and applied a methodology that has been described extensively elsewhere (Gosnell and Travis 2005). Land ownership data (acres in public and private ownership) in Wyoming were provided by county geographic information system (GIS) specialists and the Equality State Almanac (2000). Land ownership data for each county in Montana were obtained from the Montana Natural Resource Information System (MT NRIS 2003). The Departments of Revenue (DOR) in Montana and Wyoming provided data on private land ownership: specifically, detailed ownership data for all parcels designated as "agricultural" for tax purposes in 2002. In each county, we interviewed 
members of the local agricultural community, real estate agents, appraisers, conservationists, and representatives of local and federal government. We also gathered baseline data on county socioeconomic and agricultural trends from federal and state sources.

We developed ranch ownership turnover data for each of our 10 study counties by gathering sales data from real estate appraisers familiar with the areas. While satisfied with the overall comprehensiveness of the appraiser data, we expect that they inadvertently omit a small, but unknown, proportion of sales in each county. This differs somewhat from the study of farm turnover and farmer "exit and entry" (or recruitment) typical in rural sociology and agricultural economics, which focuses on how farmers retire and how family members or other farm employees become owner-operators of farms and ranches (Gale 1994). Our attention is on the transfer of the property and the type of buyer, and our results indicate that, in this land market at least, most entrants are not traditional farmers and ranchers.

We sought to "type" all the ranchland buyers and the largest current owners in each county by asking individuals familiar with the agricultural communities in each of our study counties to classify each owner using a typology developed through literature review and three pilot study counties (Table 1; see Gosnell and Travis 2005). Our typology reflects the inherent limitations of assigning each owner into only one category, but we believe it usefully distinguishes groups of landowners based on their goals and strategies regarding land management and land tenure.

Table 1. Working typology for large agricultural landowners

Traditional rancher: generally a full-time owner-operator raising livestock for profit without the aid of a ranch manager; may engage in some off-ranch work (or onranch work unrelated to livestock, e.g., outfitting) but derives the majority (or at least in many years a significant portion) of his or her income from the ranch

Part-time rancher: does his or her own ranching but often has a full-time job off the ranch; ranch income is generally less than the off-ranch income; usually smaller operations

Amenity buyer: purchases a ranch for ambience, recreation, and other amenities, not primarily for agricultural production; often an absentee owner; may have some interest in ranching but generally hires a ranch manager who makes most dayto-day decisions and does the majority of the work; or, might lease the majority of his or her land and/or cattle to a "real rancher"; majority of an amenity buyer's personal income is by definition from off-ranch sources; economic viability of the ranch is usually not an issue

Investor: buys primarily for investment, often with intent to resell in the short term.

Corporation: typically purchases ranch to function as one unit in a large network of related operations and holdings elsewhere; ranch is operated by a manager.

Developer: buys the land with intention to subdivide and sell off to others, with profits from that sale the main objective

Conservation organization: buys ranch with intent to manage for habitat, wildlife, etc.

Other: includes state and federal land management agencies, churches, independent loggers, grazing co-ops, dude ranches, etc. 


\section{Findings}

The main ranchland dynamic in the GYE involves the transition from traditional ranchers, typically full-time livestock producers, to a more diverse group of landowners, including absentee owners focused on amenity or conservation values in addition to, or instead of, livestock production, as well as investors and land developers. While the sale of a ranch may lead to subdivision or other forms of land development, especially near resorts, most of the large ranches that changed hands in the last decade in the counties we studied actually remained in large, undeveloped parcels.

Absentee ownership has been a component of the GYE's land tenure regime for over a century, but the large scale acquisition of ranches by individuals with significantly different management philosophies is a relatively new phenomenon. While this dynamic dates back to the 1970s in some areas, many of our informants indicated that it accelerated and spread throughout the region during the 1990s. All of the counties in our study area experienced strong demand for ranch properties in the 1990s, while a few locations witnessed especially rapid change, with turnover rates approaching $50 \%$.

The result is a geographical mix of ranch landscapes, with ownership regimes ranging from pockets where traditional ownership and use still dominate to areas where amenity owners and investors hold most of the land and thus determine landscape-scale use and conservation options. We present a conceptual model for distinguishing between different ranch landscapes and discuss conservation implications at the end of this article.

\section{Sales of Ranchland, 1990-2001}

We found in our 10 counties a total of 582 sales involving 400 acres or more during 1990-2001, totaling 1,479,046 acres. The number of sales ranged from a low of 38 in Madison County to a high of 88 in Fremont County (Table 2). In terms of acres sold, Beaverhead County stands out with 258,857 acres in large ranch sales, reflecting the large size of many Beaverhead ranches and the large quantity of private land in that county compared to other parts of the GYE. Similarly, Madison County, with the least number of sales (38), ranked among the highest in terms of acres sold, due to several sales of very large ranches. At the other end of the spectrum, both Carbon and Lincoln counties saw relatively few acres sold, since most of the ranches that sold were relatively small.

To assess the rate of ownership change in each county, we compared the current number of large agricultural operations with the total number of large sales in each county (Gosnell and Travis 2005). ${ }^{1}$ We found the highest rates of ownership change in the four Wyoming counties: Sublette, Lincoln, Fremont, and Park. Almost half of the large agricultural operations in Sublette changed hands during the 1990s, and almost one-third in Lincoln and Fremont. In terms of acreage, Fremont led the way, with more than one-third of its acreage in large agricultural operations changing hands. Park (Wyoming), Beaverhead, and Sublette also saw high percentages (nearly one-third) change hands. ${ }^{2}$

All together, 23\% - nearly one-quarter - of 2,547 large agricultural operations in the $10 \mathrm{GYE}$ counties changed hands in the past decade. Based on available data, we conclude that some $1,479,000$ acres - about $22 \%$ - of the land in large agricultural holdings changed hands between 1990 and 2001. 


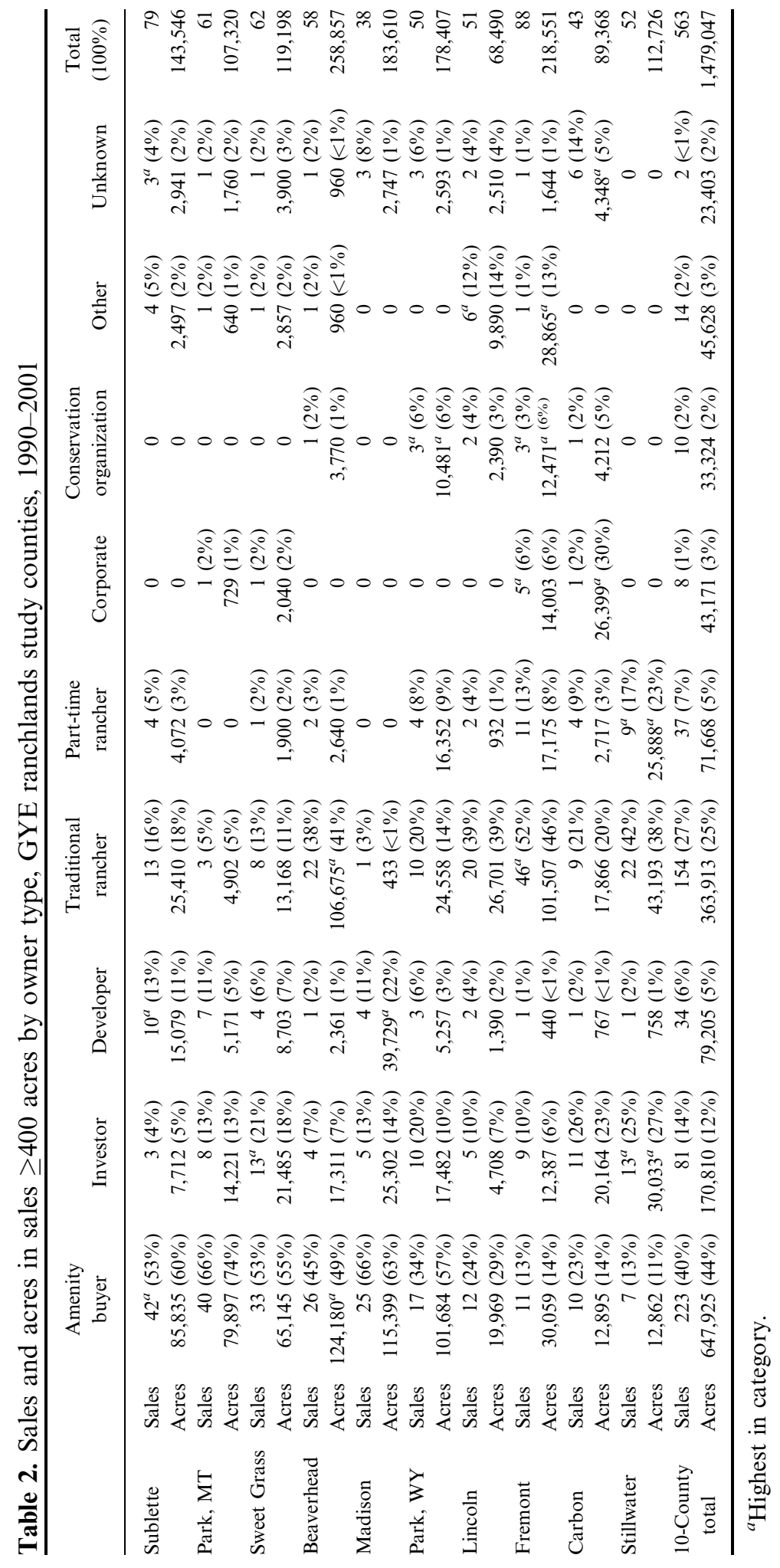




\section{Who Is Buying Ranchlands in the GYE?}

These findings raise obvious questions about who is buying ranchland and what they are doing, or likely to do, with it. We attempted to characterize ranch buyers in the GYE because, though it is widely believed that many, if not most, ranch sales are to nontraditional buyers, very little data on this important trend have been available.

Table 2 provides a complete roster of buyer types in the 10 study counties. In these counties, the most common buyers of ranchlands over the study period were amenity buyers, traditional ranchers, and investors, in descending rank order. Amenity buyers clearly dominated the ranch real estate market, purchasing $38 \%$ of the ranches and $43 \%$ of the acreage sold in the study counties. Traditional ranchers purchased $26 \%$ of the ranches and $25 \%$ of the acreage. Investors acquired $14 \%$ of the purchases and $12 \%$ of the acreage sold. Developers played a minimal role in the ranch market at the size class we examined (400+ acres), purchasing only $6 \%$ of the ranches sold. Conservation organizations purchased $2 \%$ of the ranches and $2 \%$ of the acres sold (Figure 2$)^{3}$

\section{Current Patterns of Ranchland Ownership}

The sales trends we have identified - and the small percentage of sales to developers, in particular - suggest that fragmentation due to exurban development (beyond the urban fringe) is proceeding more slowly in remote ranching counties than in areas featuring resorts and urban areas, a finding that comports with the American Farmland Trust's 2002 analysis of ranchlands "at risk" (American Farmland Trust 2002). To assess current levels of ownership fragmentation in these 10 counties, we looked at 7,822,300 acres of private land, the vast majority of which is designated as agricultural (in most cases, more than $95 \%$ ) for tax purposes. Most of it $(6,739,800$ acres or $86 \%$ ) is in what we classify as "large" operations - that is, it is owned by individuals or corporations that own a total of 400 acres or more (Figure 1).

These ranchlands are expressed in a diverse array of land tenure configurations. Beaverhead, Madison, and Sweet Grass featured the most acres in large holdings, with over $90 \%$ of agricultural land in each county designated as such, indicating relatively intact landscapes comprised mainly of large ranches. Lincoln, Sublette,

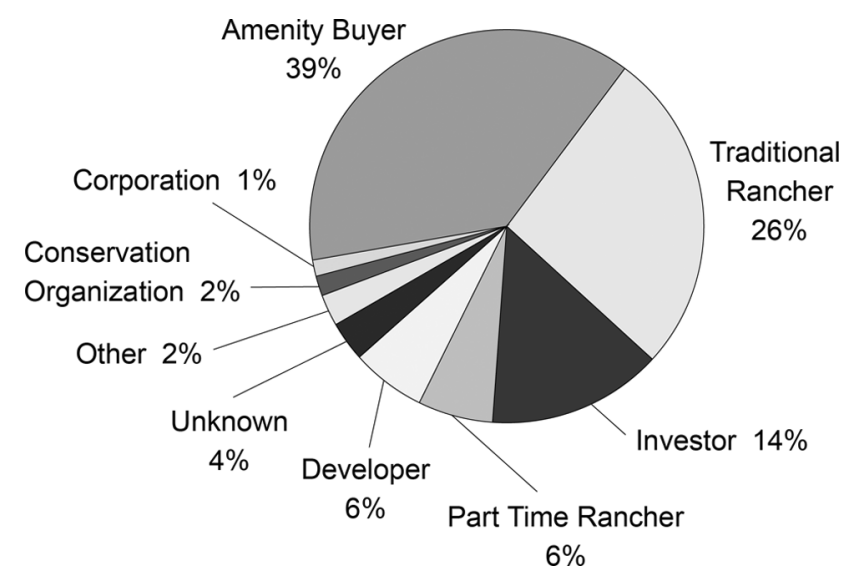

Figure 2. Percentage of ranch sales $\geq 400$ acres to different buyer types, 10-county GYE study area, 1990-2001. 
Carbon, Park (Wyoming), and Fremont counties had the least amount of acres in large agricultural operations, suggesting more fragmented agricultural landscapes. (Like Fremont County, several of these counties encompassed areas devoted to irrigated crop production, with correspondingly smaller average farm sizes.) Figure 1 shows the "large agricultural" landscape of the GYE, for example, lands owned by individual entities that own 400 or more acres of land in agricultural tax status in each county.

Our analysis of current ownership patterns also suggests that parts of the GYE currently feature as many nontraditional owners (if not more) as conventional livestock ranchers. We classified the 20 largest landowners in each county to get a feel for which type of owners dominated each county. We found that the top 20 landowners in each county collectively controlled nearly 3 million acres, almost half the land in large holdings. Traditional ranchers accounted for just over half of those acres, controlled the most land in Beaverhead, Sweet Grass, and Stillwater counties, and were the dominant group in terms of percentages of private land in Beaverhead, Sweet Grass, Sublette, and Carbon. Amenity owners in the list of the 20 largest landowners in each county controlled a quarter of the acres, and held the most land and were the dominant cohort in Madison, Park (WY), and Park (MT). In terms of raw acrage, amenity ownership was most prevelant in Beaverhead County. These findings are in line with findings from interviews that suggested that Madison, Park (WY), and Park (MT) have made the most extensive transition from primarily traditional to primarily amenity-driven ownership. We estimate from property tax records that approximately a third of all of the largeowners in our study counties are absentee.

\section{Discussion}

Turnover in ranchland in the 1990 s produced dynamics that significantly affect land management trends, and opportunities and constraints related to the conservation of the GYE's private landscapes. Our interviews revealed that buyer interests in natural amenities and investment opportunities, rather than in livestock production, guided more than half of the purchases of GYE ranches in the 1990s, suggesting the introduction of new land use values to these landscapes. Many of the region's ranch landscapes feature varying levels of representation of new, amenity-oriented owners and their conventional livestock ranching counterparts, in contrast to historical patterns in which full-time ranchers were the dominant cohort among landowners. Ownership change may therefore entail changing trust and power relations among private landowners and between private landowners and public land managers, with consequences for environmental management and conservation (Bergmann and Bliss 2004). Anecdote and our interviews with public lands managers suggest that amenity-oriented owners are more open to changes (especially reductions) in grazing permits. Ownership change may also have consequences for local government and land use decision making (Walker and Fortmann 2003; Walker et al. 2003; Hurley and Walker 2004; Walker and Hurley 2004). Amenity-oriented owners tend to prefer land use plans that limit surrounding development and thus they may clash with owners who wish to preserve their rights to subdivide and develop rural land.

Contrary to the oft-expressed fear that ranch sales inevitably put critical habitat at risk of fragmentation through development (Knight et al.1995), in the 10 GYE counties we studied, large holdings of ranchland tended to stay intact when sold. It is widely assumed (though poorly documented) that as the numbers of owners and discrete parcels in a landscape increase, so does the threat to biodiversity (based on 
the likelihood of habitat fragmentation) (Parmenter et al. 2003). Thus, our findingranches tended to stay intact when they changed hands - is generally good news for regional land conservation.

This result may partly reflect our focus on larger ranches (400 acres or greater) that could act as viable cattle operations and intact habitat, as well as our decision to exclude resort counties; developers tend to purchase smaller blocks of land. Yet among the scores of ranch sales we examined, just a few were headed toward subdivision and development, while the majority remained intact. Furthermore, the property tax data indicate that less than $15 \%$ of the private land in the study area has been fragmented into small parcels (including town sites); the rest remains in larger units. Still, our analysis of ownership patterns revealed different levels of ranchland fragmentation across the landscape. This variegation in the ownership attributes of ranch landscapes has immediate conservation implications, as different cultural and physical landscapes demand different configurations of conservation tools and strategies.

Figure 3 presents a conceptual model for marking the distinctions among different ranch landscapes that result both from parcel pattern and cultural attributes of

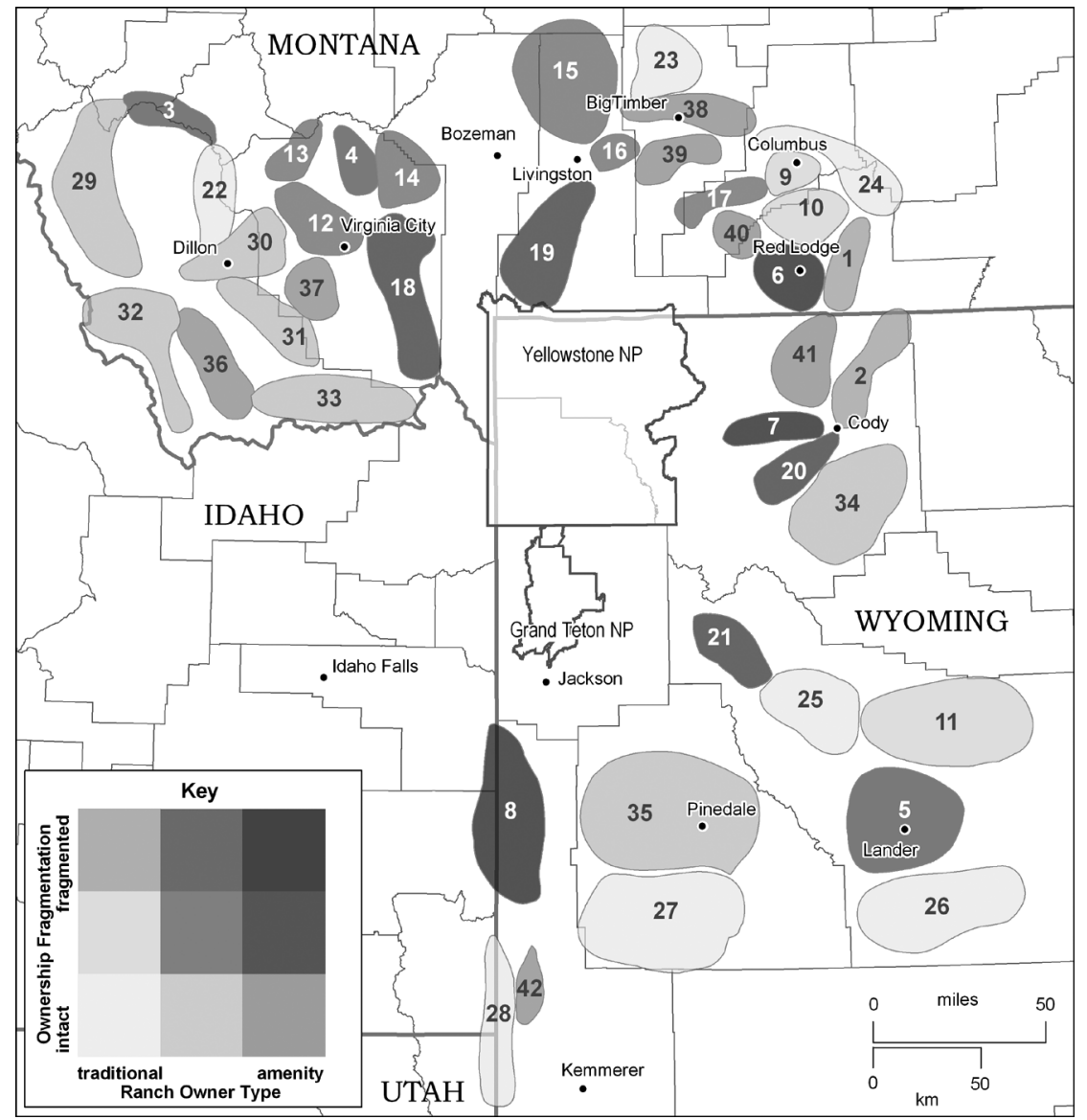

Figure 3. A conceptual matrix of ownership fragmentation and transition. 43 ranch landscapes arranged according to level of ownership fragmentation (y axis) and transition from predominantly traditional to amenity ownership (x axis). 
landowners. Our two dimensions represent the current ranching landscape as dominated by traditional versus amenity-focused ranch owners ( $x$ axis) and as relatively intact (large ranches) versus fragmented (smaller properties) on the $y$ axis. We suggest that there are three poles or vertical stacks of ranching landscapes in the matrix, grouped by predominant owner type and each suggesting distinct sets of conservation implications. We have populated the matrix with the 43 different ranch landscapes we identified, based on our data analysis and interviews with key informants. The landscapes are mapped in Figure 4.

Pole 1 describes a landscape that is largely dominated by full-time owner-operators, that is, production-oriented "traditional ranchers" in our typology. Many of these areas feature a mix of ranching and row-crop agriculture, so conservation opportunities here hinge on the cooperation of agriculturalists with conservation goals, and, in terms of ranches as a brake on rural development, on the socioeconomic sustainability of commodity agriculture. This can apply both in landscapes marked by large parcels, like the east side of the Crazy Mountains in Sweet Grass County, and in those dominated by smaller ownership units, like the Lower Clarks Fork in Carbon County. Some of the more fragmented areas, like the Lower

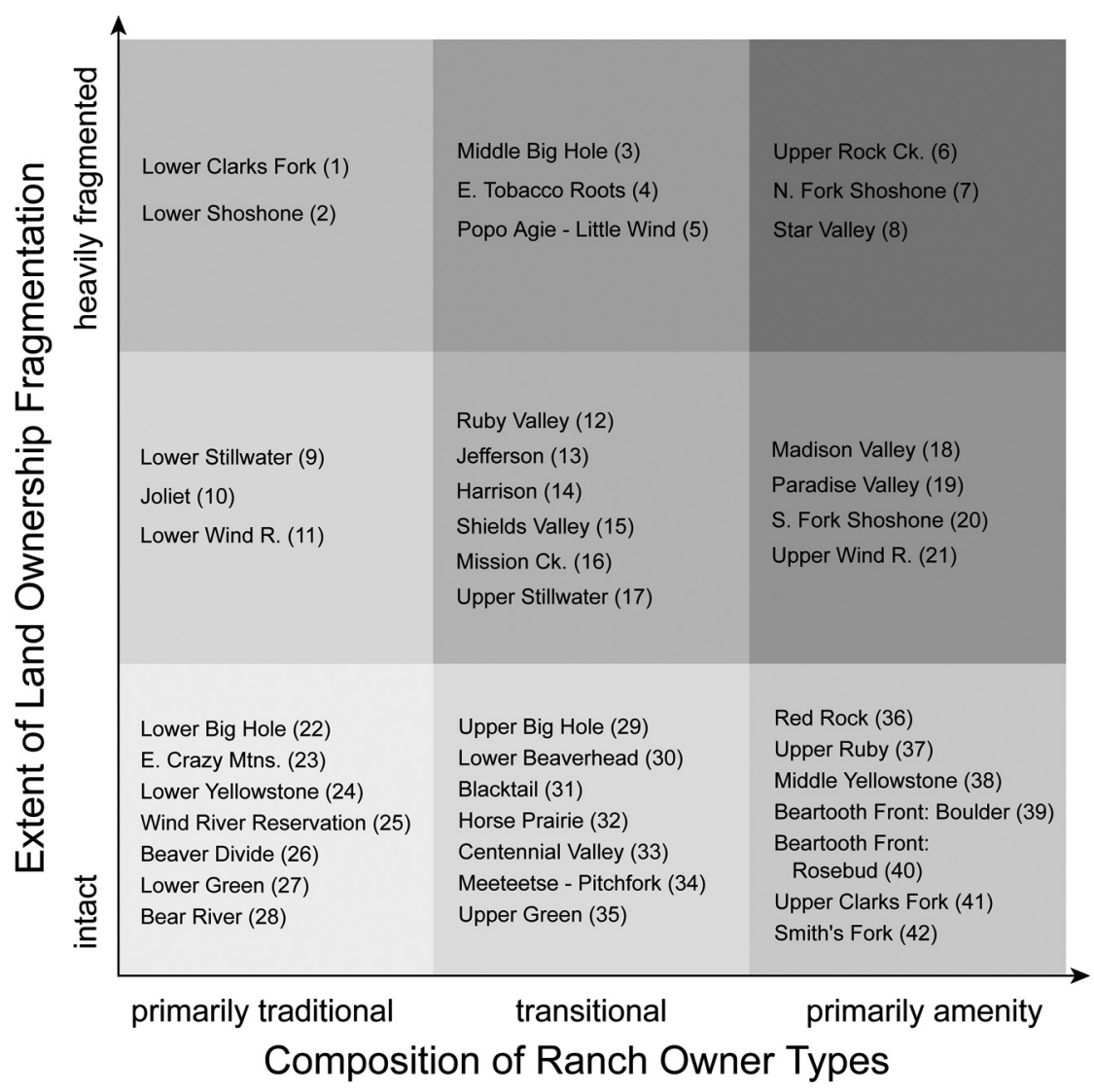

Figure 4. General location of large blocks of private land that constitute locally-identified ranch landscapes in the 10-county study area. Landscapes are numbered and shaded according to placement in Figure 3. 
Shoshone in Park County (WY), owe their existence to federal irrigation projects that are, on the one hand, quite stable, and on the other hand subject to changes in water allocation occasioned by the many forces acting on Western water, like protection of aquatic species and water transfers to cities. These are areas to which a mix of creative approaches aimed at farm and ranch viability, including grass banking, economic diversification, and irrigation efficiency improvements, might best be applied. Inadequate estate planning, which makes farms and ranches more subject to development at the moment of intergenerational turnover, continues to plague ranch continuity in some of these communities and is an obvious area for targeted conservation outreach.

Pole 2 represents landscapes in transition that have attracted some landowners with amenity priorities while retaining other, long-tenure, production-oriented owners. Landscapes in this group feature a combination of landscape elements that have become increasingly attractive to rural development in the American West: appealing wild and pastoral scenery, historic communities, isolation, wetter climate, and higher terrain. Transitional landscapes featuring heavily fragmented ownership patterns, like the Middle Big Hole in Beaverhead County and the East Tobacco Roots in Madison County, are at the highest risk of development and represent logical targets for purchases of development rights and other conservation easement tools, as remaining large parcels command an increasing premium in the land market. Lower on the pole, in areas with more intact parcel patterns-like the Upper Stillwater in Stillwater County and the Upper Green in Sublette County-opportunities exist for motivated, committed, and knowledgeable ranch managers, working for amenity-oriented owners, together with active members of the historic ranching community, to take a leadership role in the community. Such areas stand to benefit from projects to identify shared stewardship challenges, such as weed eradication and hotspots of overgrazing, in which leveraging the resources of new landowners (through private land grass banking, for example) can help sustain struggling productionfocused operators and create new strategies for accommodating ecosystems processes like wildlife migration, flood, and fire.

Ranching landscapes in the third pole have largely made the transition to alternative ownership and feature a wide variety of land use practices, ranging from "conservation ranching" to "fishing ranches" to 20-acre "ranchettes" and second homes. Absentee owners dominate these landscapes. Those areas with little ownership fragmentation that are dominated by amenity owners, like the Boulder River and Rosebud Creek areas along the Beartooth Front in Sweet Grass and Stillwater Counties, respectively, are often the bulwark of regional private land protection efforts, providing a secure base of lands protected by conservation easements as well as financial and social resources that spill over into other areas. Amenity-dominated landscapes with intermediate fragmentation, like the Madison Valley in Madison County and the Paradise Valley in Park County (MT), suggest a risk of future fragmentation, but also offer prime opportunities to achieve conservation outcomes by encouraging conservation actions, innovative development, and investment strategies as outside capital pours in. This might include, for example, reaggregating subdivided ranches, or encouraging owners to purchase neighboring properties as they come up for sale to maximize both privacy and habitat continuity. Amenity landscapes that are heavily fragmented typically accompany resort development or some other major population draw, like the east entrance to Yellowstone National Park at the head of the North Fork of the Shoshone. Some of the landscapes in this 
category, however, like the Star Valley in Lincoln County, owe their fragmented nature to previous agricultural geographies (in the case of the Star Valley, a history of smaller dairy farms that systematically went out of traditional hands as the dairy industry faltered and outsiders - many from the Salt Lake City area-became aware of the tremendous fishing opportunities along the Salt River). These landscapes reflect the kinds of conservation challenges and opportunities typical of many of the West's exurban zones, including the need for design standards and ordinances that reduce the ecological footprint of development through, for example, regulations to reduce the impact of roads, construction sites, and even garbage management.

\section{Conclusions}

While development of private lands in this and other protected ecosystems in the United States is the preeminent threat to ecosystem integrity, our results point to the importance of recognizing and further studying changes in ownership and land use on larger, undeveloped private land parcels. The high level of activity by nontraditional buyers in ranch acquisitions in the 1990s means that most GYE ranching landscapes are now strongly affected by amenity and investment ownership, with mixed implications for land conservation. Traditional conflicts - for example, between predators and livestock - may be lessened by owners who count wildlife, even predators, as an amenity. But such owners also bring other land use preferences: discouraging hunting and frustrating efforts to manage ungulate populations; switching use of water from irrigation to trout habitat; and building large residences and restricting public access. Conservation groups are encouraging the purchase of ranches by buyers who count conservation itself as an amenity, and some real estate brokers in the GYE now specialize in conservation properties. Amenity ranchers are in a financial position to relax ranching intensity, but may not take a comprehensive ecological approach to restoration. There is an obvious need here for effective outreach and information, but also a challenge in developing communications with new buyers. Working for amenity owners, ranch managers, who will increasingly dominate on-the-ground ranch operations in such areas, also represent an obvious audience for conservation outreach. Loss of local knowledge should be a concern regarding both public lands and common problems like water and weeds, suggesting the need for efforts to build bridges between new and established landowners.

It is also difficult to judge the stability of the new ownership regime. While continuity of family ownership across generations is often a central goal of traditional ranch operations, we do not know how long new amenity owners are likely to hold onto large properties, nor how the transition from one amenity owner to another, or among investors, is likely to play out. While some conservation benefits certainly accrue as new owners create large ranch reserves and seek explicit conservation goals (like protecting and improving wildlife habitat), a great question remains as to their long-term plans and likely persistence in the GYE. We found cases of new ranch empires built quickly (often disrupting local land and labor supply) and just as quickly liquidated. And we found cases of new ranchers with outside sources of wealth becoming committed to and well integrated into local communities, suggesting that they are there for the long haul, but it is hard to predict whether and how future generations will keep or dispose of these properties. It may be too early in this major transition of ranchland ownership to assess likely future stability. 
It also remains to be seen whether amenity buying also means more conservation easements and other legal protections for land. Investment-oriented buyers will resist easements if they result in a lower resale value, and easements appear to have played only a minor role in stemming the tide of family operations selling out. Important exceptions to this occur where funding for easements has been greater, as in Beaverhead County, Montana. Still, unless ranchlands are placed under some form of conservation easement (with resources provided for long-term conservation management), the current transition probably implies a long period of instability in ranchland status and uncertainty about the role ranchlands will play in maintaining the ecological integrity of the Greater Yellowstone Ecosystem.

Next steps in this line of research should include a better understanding of the land use practices of new owners, and how the historical, cultural, and physiographic idiosyncrasies of local landscapes merge with the different primary purposes of individual private ranches to affect "transboundary" and landscape-scale ecological processes.

\section{Notes}

1. Since some of the sales were repeat sales of the same property, this may slightly overestimate rates of change.

2. Data on the number of and acres in large agricultural operations in 1990 were not available, so we used 2001 numbers as an approximation. There may have been more large operations in 1990 due to subdivisions (making our calculations an over estimate), or the agglomeration of lands into larger spreads may have offset this trend.

3. We hypothesize that the small percentage of sales to developers is a function of our focus on ranches greater than or equal to 400 acres in size. Developers looking for a property to subdivide would, in most cases, target a smaller parcel.

\section{References}

American Farmland Trust. 2002. Strategic ranchland in the Rocky Mountain West: Mapping the threats to prime ranchland in seven western states. Washington, DC: American Farmland Trust. Accessed May 5, 2005 from http://www.farmland.org/rocky_mountain/strategic_ ranchlands1.htm.

Bergmann, S. A. and J. C. Bliss. 2004. Foundations of cross-boundary cooperation: Resource management at the public-private interface. Society Nat. Resources 17(5):377-393.

Brunson, M. W. 1998. Social dimensions of boundaries: Balancing cooperation and self-interest. In Stewardship across boundaries, eds. R. L. Knight and P. B. Landres, 65-86. Washington, DC: Island Press.

Equality State Almanac. 2000. 8th ed. Cheyenne, WY: Department of Administration and Information, Division of Economic Analysis. Accessed August 7, 2003, from http:// eadiv.state.wy.us/almanac/almanac.asp.

Fortmann, L. and J. Kusel. 1990. New voices, old beliefs: Forest environmentalism among new and long-standing rural residents. Rural Sociol. 55(2):214-232.

Franklin, J. F. 1993. Preserving biodiversity: Species, ecosystems, or landscapes. Ecol. Appl. 3(2):202-205.

Frentz, I. C., F. L. Farmer, J. M. Guldin, and K. G. Smith. 2004. Public lands and population growth. Society Nat. Resources 17(1):57-68.

Gale, F. 1994. The new generation of American farmers: Farm entry and exit prospects for the 1990s. AERR Report No. 695. Washington, DC: USDA Economic Research Service.

Glick, D. A., M. Carr, and B. Harting. 1991. An environmental profile of the Greater Yellowstone Ecosystem. Bozeman, MT: Greater Yellowstone Coalition. 
Glick, D. A. and T. W. Clark. 1998. Overcoming boundaries: The Greater Yellowstone Ecosystem. In Stewardship across boundaries, eds. R. L. Knight and P. B. Landres, 237-256. Washington, DC: Island Press.

Gosnell, H. and W. R. Travis. 2005. Ranchland ownership dynamics in the Rocky Mountain West. Rangeland Ecol. Manage. 58(2):191-198.

Graber, E. F. 1974. Newcomers and oldtimers: Growth and change in a mountain town. Rural Sociol. 39(4):504-513.

Greater Yellowstone Coalition. 1994. Sustaining Greater Yellowstone: A blueprint for the future. Bozeman, MT: Greater Yellowstone Coalition.

Groom, M., D. B. Jensen, R. L. Knight, S. Gatewood, L. Mills, D. Boyd-Heger, L. S. Mills, and M. E. Soule. 1999. Buffer zones: Benefits and dangers of compatible stewardship. In Continental conservation: Scientific foundations of regional reserve networks, eds. M. E. Soule and J. Terborgh, 171-197. Washington, DC: Island Press.

Haggerty, J. H. and W. R. Travis. In press. Out of administrative control: Absentee owners, resident elk and the shifting nature of wildlife management in southwestern Montana. Geoforum.

Hansen, A. J., R. Rasker, B. Maxwell, J. J. Rotella, J. D. Johnson, A. W. Parmenter, U. Langner, W. B. Cohen, R. L. Lawrence, and M. P. V. Kraska. 2002. Ecological causes and consequences of demographic change in the New West. Bioscience 52(2):151-162.

Hansen, A. J. and J. J. Rotella. 2002. Biophysical factors, land use, and species viability in and around nature reserves. Conserv. Biol. 16(4):1112-1122.

Hurley, P. T. and P. A. Walker. 2004. Whose vision? Conspiracy theory and land-use planning in Nevada County, California. Environ. Plan. A 36(9):1529-1547.

Jones, R. E., J. M. Fly, J. Talley, and H. K. Cordell. 2003. Green migration into rural America: The new frontier of environmentalism? Society Nat. Resources 16(3):221-238.

Knight, R. L. and P. B. Landres. 1998. Stewardship across boundaries. Washington, DC: Island Press.

Knight, R. L., G. N. Wallace, and W. E. Riebsame. 1995. Ranching the view: Subdivisions versus agriculture. Conserv. Biol. 9(2):459-461.

Lowe, G. D. and T. K. Pinhey. 1982. Rural-urban differences in support for environmental protection. Rural Sociol. 47(1):114-128.

Lucas, P. H. C. 1992. Protected landscapes: A guide for policy-makers and planners. Gland, Switzerland: International Union for the Conservation of Nature, and London: Chapman and Hall.

Montana Natural Heritage Program. 2003. Land ownership and managed areas in Montana. Helena: Montana State Library, February 7. Accessed April 23, 2003, from http://nris. state.mt.us/nsdi/nris/ab105/ownerse.html.

Montana Natural Resources Information System. 2003. Accessed June 8, 2003, from http:// nris.state.mt.us.

Noss, R. F., C. Carroll, K. Vance-Borland, and G. Wuerthner. 2002. A multicriteria assessment of the irreplaceability and vulnerability of sites in the Greater Yellowstone Ecosystem. Conserv. Biol. 16(4):895-908.

Parmenter, A. W., A. Hansen, R. E. Kennedy, W. Cohen, U. Langner, R. Lawrence, B. Maxwell, A. Gallant, and R. Aspinall. 2003. Land use and land cover change in the Greater Yellowstone Ecosystem: 1975-1995. Ecol. Appl. 13(3):687-703.

Riebsame, W. E., H. Gosnell, and D. M. Theobald. 1996. Land use and landscape change in the Colorado mountains I: Theory, scale, and pattern. Mountain Res. Dev. 16(4):395-405.

Rudzitis, G. 1996. Wilderness and the changing American West, New York: John Wiley \& Sons.

Rudzitis, G. 1999. Amenities increasingly draw people to the rural West. Rural Dev. Perspect. 14:9-13.

Smith, M. and R. Krannich. 2000. Culture clash revisited: Newcomer and longer-term residents' attitudes toward land use, development, and environmental issues in rural communities in the Rocky Mountain West. Rural Sociol. 65(3):396-421. 
Soule, M. E. and J. Terborgh. 1999. Continental conservation: Scientific foundations of regional reserve networks, Washington, DC: Island Press.

Tanaka, J. A., N. R. Rimbey, and L. A. Torell. 2004. New faces: What does it mean for sustainable rangeland management? In Current issues in rangeland resource economics, eds. L. A. Torell, N. R. Rimbey, and L. Harris, 1-10. Utah Agricultural Experiment Station Research Report 190, Logan: College of Agriculture, Utah State University.

Theobald, D. M., H. Gosnell, and W. E. Riebsame. 1996. Land use and landscape change in the Colorado mountains II: A case study of the East River Valley. Mountain Res. Dev. 16(4):407-418.

Walker, P. A. and L. P. Fortmann. 2003. Whose landscape? A political ecology of the "exurban" Sierra. Cultural Geogr. 10(4):469-491.

Walker, P. A. and P. T. Hurley. 2004. Collaboration derailed: The politics of "communitybased" resource management in Nevada County. Society Nat. Resources 17(8):735-751.

Walker, P. A., S. J. Marvin, and L. P. Fortmann. 2003. Landscape changes in Nevada County reflect social and ecological transitions. Calif. Agric. 57(4):115-121.

Zimmerer, K. S. 2000. The reworking of conservation geographies: Nonequilibrium landscapes and nature-society hybrids. Ann. Assoc. Am. Geogr. 90(2):356-369.

Zimmerer, K. S. and K. R. Young. 1998. Introduction: The geographical nature of landscape change. In Nature's geography: New lessons for conservation in developing countries, eds. K. S. Zimmerer and K. R. Young, 3-43. Madison: University of Wisconsin Press. 